\title{
Analisis Pengaruh Instrumen Moneter Syariah dan Konvensional Terhadap Penyaluran Dana ke Sektor Usaha Mikro Kecil dan Menengah (UMKM) di Indonesia
}

\section{Analysis of the Impact of Islamic and Conventional Monetary Instruments towards Financing of Micro, Small and Medium Enterprises Sector in Indonesia}

\author{
${ }^{1}$ Masyitha Mutiara Ramadhan dan ${ }^{2}$ Irfan Syauqi Beik \\ ${ }^{1}$ Asisten Peneliti, Pusat Studi Bisnis dan Ekonomi Syariah IPB \\ ${ }^{2}$ Ketua Program Studi Ilmu Ekonomi Syariah, Fakultas Ekonomi dan Manajemen IPB
}

\begin{abstract}
As monetary authority, Bank Indonesia has developed Islamic Bank Indonesia Certificate (abbreviated as SBIS) as Islamic monetary instrument in addition to Bank Indonesia Certificate (known as $\mathrm{SBI}$ ), which has become conventional instrument. Both instruments play significant role in the transmission of monetary instrument towards real sector of the economy. Monetary transmission could take place through credit channel or financing channel, from which the fund is used as the source of credit and financing for micro, small and medium enterprises (MSME). This study aims at analyzing the impact of both Islamic and conventional monetary instruments towards MSME financing. Data used in this research is taken from Bank Indonesia, Ministry of Cooperative and SME, and Central Board of Statistics for the period of May 2006 until December 2010. The study employs Vector Auto Regression model, Impulse Response Function technique and Forecast Error Variance Decomposition (FEVD) as its analytical methods. It is found that SBI and SBIS have significant impact towards credit and financing to the MSME. When there is monetary shock, the study finds that MSME financing of Islamic bank could be recovered and stabilized better than MSME credit of conventional bank. FEVD analysis shows that the impact of SBIS towards financing of MSME is bigger than the SBI.
\end{abstract}

Keywords: Monetary instrument, banking sector, MSME, VAR

\begin{abstract}
Abstrak. Sebagai otoritas moneter, Bank Indonesia telah menjadikan Sertifikat Bank Indonesia Syariah (SBIS) sebagai salah satu instrumen kebijakan moneter syariah di samping Sertifikat Bank Indonesia (SBI) yang menjadi instrumen moneter konvensional. Kedua instrumen tersebut memiliki peran dalam mentransmisikan kebijakan moneter kepada sektor riil. Transmisi moneter dapat terjadi melalui jalur kredit, yaitu dengan penyaluran dana dari perbankan termasuk melalui kredit dan pembiayaan UMKM. Penelitian ini bertujuan untuk menganalisis pengaruh instrumen moneter syariah dan konvensional terhadap penyaluran dana ke sektor UMKM. Data yang digunakan dalam penelitian ini bersumber dari Bank Indonesia, Kemenkop dan BPS dari periode Mei 2006 sampai Desember 2010. Analisis data menggunakan model Vector Auto Regression, teknik Impulse Response Function dan Forecast Error Variance Decomposition (FEVD). Hasil analisis menunjukan bahwa SBI dan SBIS memiliki pengaruh yang signifikan terhadap penyaluran dana ke sektor UMKM, baik dari jalur perbankan syariah maupun konvensional. Selain itu, pembiayaan UMKM perbankan syariah lebih cepat stabil dibandingkan dengan kredit UMKM perbankan konvensional saat terjadi guncangan moneter. Sedangkan hasil FEVD menunjukan bahwa pengaruh SBIS terhadap penyaluran dana ke sektor UMKM lebih besar dibandingkan SBI.
\end{abstract}

Kata kunci: Instrumen moneter, sektor perbankan, UMKM, VAR 


\section{PENDAHULUAN}

Dunia mengakui bahwa usaha mikro, kecil, dan menengah (UMKM) memainkan peran yang sangat vital di dalam pembangunan dan pertumbuhan ekonomi, tidak hanya di negara-negara sedang berkembang tetapi juga di negara maju. Negara - negara maju seperti Amerika Serikat, Jepang, Prancis dan Belanda telah menjadikan sektor UMKM sebagai motor penggerak perekonomian negaranya, yaitu sebagai pemicu pertumbuhan ekonomi, inovasi dan progres teknologi (Tambunan, 2009).

Sektor UMKM juga memiliki peran yang penting dalam perekonomian Indonesia. Pada tahun 2010 sektor ini mampu menyerap 97,3 persen dari total tenaga kerja. Hal ini menunjukan bahwa sektor UMKM adalah sektor utama dalam penyerapan tenaga kerja di Indonesia yang apabila dikembangkan berpotensi mengurangi pengangguran karena jumlah unit usaha UMKM mencapai 52.764.603 unit atau 99 persen dari total usaha yang ada. Selain itu, lebih dari setengah atau 56,5 persen PDB Indonesia disumbangakan oleh sektor ini. Begitu juga dengan pendapatan ekspor non-migas, sektor UMKM mampu menyumbang 17,04 persen dari pendapatan total.

Pada kenyataannya perkembangan sektor UMKM di Indonesia masih dihadapkan oleh berbagai masalah. Salah satu masalah mendasar yang dihadapi adalah keterbatasan modal kerja dan investasi. Bedasarkan data dari Badan Pusat Statistik (BPS) pada tahun 2010, hanya 20,49 persen usaha mikro dan kecil yang memanfaatkan pinjaman dan sebagian besar pinjaman berasal dari perorangan, bukan dari lembaga keuangan formal atau perbankan. Permodalan mereka tergantung sepenuhnya pada tabungan sendiri atau sumber-sumber informal seperti keluarga.

Sejak tahun 1970-an, pemerintah telah memfasilitasi penyaluran dana ke sektor usaha kecil mikro dan menengah (UMKM) yang diawali dengan dua skema kredit dari Bank Indonesia yaitu Kredit Modal Kerja Permanen (KMKP) dan Kredit Investasi Kecil (KIK). Selain itu Bank Indonesia telah mengeluarkan Peraturan Bank Indonesia (PBI) Nomor 3/2/PBI/20011 yang mewajibkan perbankan untuk menyediakan 20 persen dari total kreditnya kepada usaha kecil. Peraturan tersebut dikeluarkan untuk mendorong perbankan agar meningkatkan penyaluran dana ke sektor UMKM. Melihat besarnya peran UMKM di Indonesia maka wajar apabila sektor ini mendapat perhatian lebih, khususnya dari segi akses dan permodalan yang selama ini menjadi permasalahan utama dalam pengembangan UMKM.

Sebagai negara yang menganut sistem moneter ganda, Bank Indonesia telah menerbitkan Sertifikat Bank Indonesia Syariah (SBIS) sebagai instrumen moneter syariah yang berdampingan dengan Sertifikat Bank Indonesia (SBI) yang selama ini dipakai sebagai instrumen moneter konvensional. SBIS adalah surat berharga bedasarkan prinsip syariah berjangka waktu pendek dalam mata uang rupiah yang diterbitkan oleh Bank Indonesia dalam rangka meningkatkan efektifitas mekanisme moneter dengan prinsip syariah. SBIS mulai digunakan sebagai instrumen moneter sejak tahun 2008, menggantikan peran instrumen moneter syariah sebelumnya, yaitu Sertifikat Wadiah Bank Indonesia (SWBI). Perbedaan SBIS dan SWBI hanya terletak pada akad yang digunakan ${ }^{1}$. Sebagai Instrumen moneter, SBI dan SBIS memiliki jalur transmisi tersendiri terhadap sektor riil dimana instrumen ini akan mempengaruhi besarnya pembiayaan dan peyaluran kredit kepada sektor riil.

\footnotetext{
${ }^{1}$ Akad yang digunakan pada SWBI adalah wadiah, sementara akad yang digunakan pada SBIS adalah ju'alah. Akad wadiah adalah akad titipan, dimana para investor menitipkan dananya pada Bank Indonesia melalui SWBI, dan Bank Indonesia dapat memberikan bonus kepada para investor sesuai dengan kebijakan yang ada. Bonus ini tidak boleh dijanjikan di awal. Sedangkan akad jualah adalah akad dimana para investor, seperti bank syariah, bertindak sebagai pihak yang membantu Bank Indonesia dalam menstabilkan kondisi moneter. Bank Indonesia kemudian memberikan bonus sebagai imbalan atas jasa para investor yang telah membantu menstabilkan kondisi moneter.
} 
Baik bank syariah maupun bank konvensional memiliki tugas utama sebagai lembaga intermediasi, yaitu menyalurkan dana dari pihak surplus ke pihak yang memerlukan dana secara optimal. Salah satu jalur intermediasi perbankan adalah melalui penyaluran dana kepada UMKM, yaitu penyaluran dana yang dialokasikan untuk investasi atau pengembangan usaha masyarakat berskala mikro, kecil atau menengah. Pemberian kredit kepada dunia usaha khususnya di sektor UMKM perlu ditingkatkan dalam upaya meningkatkan peran perbankan nasional sebagai lembaga intermediasi (Meydianawathi, 2007). Bank sebagai penghimpun dan penyalur dana masyarakat harus dapat mengelola saluran kredit dan pembiayaan secara tepat sehingga dapat menjembatani sektor keuangan dan sektor rill. Selain itu, bank sebagai lembaga keuangan yang dominan di Indonesia seharusnya mendukung penuh keberadaan dan perkembangan UMKM mengingat peran UMKM yang sangat besar bagi perekonomian.

Sesuai dengan Peraturan Bank Indonesia Nomor 3/2/PBI/2001, perbankan konvensional maupun perbankan syariah dianjurkan untuk menjadikan pembiayaan sektor UMKM sebagai prioritas dan berkomitmen untuk terus mempermudah akses UMKM terhadap perbankan. Hal ini tercermin dari porsi kredit UMKM yang mencapai lebih dari empat puluh persen dari kredit total pada perbankan konvensional. Bahkan porsi pembiayaan UMKM pada bank syariah mencapai lebih dari tujuh puluh persen dari pembiayaan total.

Penyaluran dana ke sektor UMKM lewat perbankan tentunya dipengaruhi oleh banyak faktor, baik faktor internal maupun faktor eksternal. Dari berbagai studi terdahulu, faktor internal yang mempengaruhi penyaluran kredit dari perbankan antara lain faktor rentabilitas dan profitabilitas. Sedangkan dari faktor eksternal, penyaluran kredit dari perbankan dipengaruhi oleh instrumen moneter. Hal inilah yang menjadi salah satu alasan bahwa penelitian mengenai pengaruh instrumen syariah dan konvensional terhadap pembiayaan UMKM di Indonesia penting untuk dilakukan karena akan mempengaruhi tindakan perbankan konvensional maupun syariah dalam menyalurkan dananya ke sektor UMKM. Oleh karena itu, penelitian ini menganalisis secara kuantitatif pengaruh instrumen moneter dan perbankan terhadap pembiayaan UMKM di Indonesia.

Penelitian ini bertujuan untuk mengidentifikasi pengaruh instrumen moneter syariah dan konvensional terhadap pembiayaan UMKM dari perbankan syariah dan konvensional di Indonesia. Selain itu penelitian ini akan membandingkan pengaruh instrumen moneter syariah dan konvensional terhadap pembiayaan ke sektor UMKM di Indonesia.

\section{TINJAUAN PUSTAKA}

Transmisi moneter adalah mekanisme bekerjanya kebijakan moneter samapi memengaruhi sektor riil. Mishkin (2004) menjelaskan bahwa jalur mekanisme transmisi moneter dapat terjadi melalui beberapa jalur, yaitu jalur efek suku bunga tradisional (traditional interest rate effect), jalur efek harga asset lain (other asset price effect) dan jalur kredit (credit view). Penyaluran dana untuk sektor UMKM dari perbankan dapat diklasifikasikan ke jalur bank lending channel karena bank memiliki peran yang penting dalam sistem keuangan, yaitu sebagai lembaga intermediasi sekaligus penyalur kredit dan pembiayaan terhadap masyarakat, termasuk kepada sektor UMKM.

Dalam proses transmisnya, Bank Indonesia dapat melakukan kontraksi dan ekspansi moneter dengan menaikan atau menurunkan suku bunga kebijakan (BI Rate). Kebijakan ini akan mempengaruhi sisi liabilitas (kewajiban) bank yang di dominasi oleh dana pihak ketiga (DPK) yaitu dana masyarakat yang disimpan di perbankan. Ketika ekonomi memanas, Bank Indonesia melakukan kontraksi moneter dengan menaikan BI Rate. Kebijakan ini akan menyebabkan jumlah uang beredar di masyarakat akan turun sehingga mengakibatkan jumlah DPK juga ikut menurun. Penurunan DPK akan mengakibatkan penurunan ketersediaan dana yang siap 
disalurkan oleh perbankan, salah satunya dalam bentuk kredit. Untuk meningkatkan DPK perbankan akan cenderung menaikan suku bunga dana (tabungan, deposito) sehingga berakibat pada kenaikan suku bunga kredit. Permintaan terhadap kreditbaru cenderung turun karena suku bunga kredit yang meningkat dan menyebabkan investasi turun dan pertumbuhan ekonomi melambat.

Bank Indonesia juga dapat melakukan kontraksi moneter dengan peningkatan Giro Wajib Minimum (GWM). Peningkatan Giro wajib minimum akan mempengaruhi sisi liabilitas perbankan secara langsung sehingga dana yang siap disalurkan juga akan cenderung menurun. Hal ini juga akan meningkatkan suku bunga kredit dan menurunkan permintaan terhadap kredit baru sehingga investasi juga menurun. Investasi yang menurun akan menurunkan pertumbuhan ekonomi.

Dalam menjalankan kebijakan moneter Bank Indonesia memiliki beberapa instrumen moneter yaitu operasi pasar terbuka atau open market operation (OPT), giro wajib minimum (GWM), fasilitas diskonto, dan intervensi mata uang asing. Sertifikat Bank Indonesia (SBI) dan Sertifikat Bank Indonesia Syariah (SBIS) adalah salah satu instrumen yang digunakan oleh bank sentral dalam menjalankan operasi pasar terbuka. Peraturan Bank Indonesia nomor 4/10/PBI/2002 tentang Sertifikat Bank Indonesia (SBI) menyatakan bahwa SBI adalah surat berharga dalam mata uang rupiah yang diterbitkan bank Indonesia sebagai pengakuan utang berjangka waktu pendek. SBI ditebitkan oleh Bank Indonesia sebagai salah satu piranti dalam Operasi Pasar Terbuka (OPT). Sedangkan Peraturan Bank Indonesia nomor 10/11/PBI/2008 tentang Sertifikat Bank Indonesia Syariah menyatakan bahwa SBIS adalah surat berharga bedasarkan prinsip syariah berjangka waktu pendek dalam mata uang rupiah yang diterbitkan oleh Bank Indonesia menggunakan akad Jua'lah. SBIS dibuat oleh Bank Indonesia dalam rangka meningkatkan efektifitas mekanisme moneter dengan prinsip syariah. Kedua instrumen ini memiliki fungsi yang sama yaitu sebagai instrumen Operasi Pasar Terbuka dalam rangka pengendalian moneter dengan tujuan akhir kestabilan nilai rupiah dan tingkat inflasi.

Penelitian mengenai mekanisme transmisi moneter melalui jalur kredit atau pinjaman sudah cukup banyak dilakukan. Salah satunya penelitian yang dilakukan oleh Rusydiana (2009), yang menyimpulkan bahwa semakin tinggi SWBI yang ditetapkan bank Indonesia maka akan semakin rendah pembiayaan yang dilakukan oleh perbankan syariah. Selain itu terdapat hubungan yang negatif antara pembiayaan syariah dan SBI. Semakin tinggi SBI akan menyebabkan penurunan pembiayaan syariah dan sebaliknya. Hal ini disebabkan jika bank sentral menaikan suku bunga maka akan memicu perbankan konvensional untuk menaikan suku bunganya, baik pinjaman maupun deposito. Oleh karena itu, daya saing perbankan syariah akan turun dan menjadi kurang kompetitif.

Selain itu, penelitian yang dilakukan Ayyuniah (2010) menyatakan bahwa instrumen moneter konvensional memberikan guncangan yang lebih besar terhadap pertumbuhan sektor riil dibandingkan dengan instrumen moneter syariah karena proporsi instrumen konvensional yang masih mendominasi sampai dengan 97 persen dari share perbankan nasional Indonesia. Akan tetapi, instrumen moneter syariah memiliki karakteristik yang lebih stabil dibandingkan dengan variabel moneter konvensional karena lebih cepat menemukan titik kestabilan dibandingkan dengan instrumen moneter konvensional. Selain itu,dapat disimpulkan bahwa kebijakan moneter baik ekspansif maupun kontraktif dengan instrument suku bunga SBI, tidak mampu mempengaruhi jumlah penawaran kredit investasi perbankan umum, hal ini menjadi bukti bahwa kebijakan moneter melalui jalur bank lending tidak berlangsung di Indonesia selama periode 2001-2007.

Penelitian lain dilakukan oleh Muslim (2008), dimana berdasarkan hasil pengujian VAR/VECM terdapat hubungan negatif antara SBI terhadap penawaran kredit investasi dan suku bunga kredit berpengaruh positif terhadap penawaran kredit. Selain itu, penawaran kredit investasi oleh perbankan secara positif dipengaruhi oleh tingkat permodalan. Akan tetapi, dalam jangka 
panjang kredit investasi secara signifikan dipengaruhi oleh struktur keuangan perbankan itu sendiri yang mana jika perbankan diberikan penawaran kredit sebesar satu miliar maka penawaran kredit investasi akan meningkat sebesar 0,77 Miliar Rupiah. Hal ini sejalan dengan penelitian yang dilakukan oleh Wulandari (2008) yang menyatakan bahwa penawaran kredit perbankan dipengaruhi secara signifikan dan negatif oleh SBI sebagai instrumen moneter.

Adapun penelitian yang di lakukan oleh Oliver (2003) dengan studi kasus di negara Jerman menyatakan bahwa pinjaman yang diberikan bank memiliki hubungan yang positif terhadap suku bunga pinjaman dan modal, tetapi memiliki hubungan yang negatif dengan instrumen moneter. Dengan metode IRF, guncangan pada kebijakan moneter akan dengan cepat menurunkan pinjaman dari perbankan karena bank akan mengalami penurunan keuntungan dan modal.

\section{METODE PENELITIAN}

\subsection{Jenis dan Sumber Data}

Jenis data yang digunakan adalah data sekunder berupa time series bulanan periode Mei 2006 sampai dengan Desember 2010. Sumber data di dapat dari Statistik Ekonomi dan Perbankan Indonesia (SEKI), Statistik Perbankan Indonesia (SPI) dan Statistik Perbankan Syariah Bank Indonesia (SPSBI) dan Biro Pusat Statistik, dan Kementrian Koperasi dan Usaha Kecil Menengah.

\subsection{Metode Penelitian}

Vector Autoregresisve (VAR) adalah salah satu model estimasi yang digunakan kembangkan oleh Cristoper A. Sims pada tahun 1980. Sims menyatakan bahwa apabila terdapat hubungan yang simultan atau hubungan sebab akibat antar variabel yang diamati, semua variabel harus diperlakukan sama sehingga tidak lagi ada variabel endogen maupun variabel endogen, sehingga pada konsep VAR semua variabel adalah peubah endogen. VAR adalah model yang apriori terhadap teori ekonomi namun sangat berguna dalam menentukan tingkat eksogenitas suatu variabel ekonomi dalam sebuah sistem ekonomi dimana terjadi saling ketergantungan antar variabel dalam ekonomi. Model VAR juga menjadi dasar dalam pengembangan metode kointegrasi johansen yang mampu menjelaskan dengan baik perilaku variabel dalam perekonomian. Model VAR secara matematis dapat dituliskan (Pasaribu,2003) :

$$
Z_{t}=\sum_{i=1}^{k} A_{i} Z_{t-1}+B X_{t}+\varepsilon_{t}
$$

Dengan:

$\mathrm{Z}_{\mathrm{t}} \quad$ : vektor dari variabel - variabel endogen sebanyak $m$

$\mathrm{X}_{\mathrm{t}}$ : vektor dari variabel - variabel eksogen sebanyak $d$ termasuk di dalamnya konstanta (intercept)

$\mathrm{A}_{1}, \ldots, \mathrm{A}_{\mathrm{p}}$ dan $\mathrm{B}$ : matriks - matriks koefisien yang akan diestimasi

$\varepsilon_{t}$ : vektor dari residual - residual yang secara kontemporer berkorelasi tetapi tidak berkorelasi dengan nilai - nilai lag mereka sendiri dan juga tidak berkorelasi dengan seluruh variabel yang ada dalam sisi kanan persamaan di atas.

Vector Error Correction Model dilakukan jika terdapat variable yang tidak stasioner pada level. VECM adalah bentuk VAR yang terekstriksi. Restriksi tambahan ini harus diberikan karena keberadaan bentuk data yang tidak stasioner namun terkointegrasi. Dengan menggunakan 
metode VECM maka akan didapatkan dampak jangka panjang dan jangka pendek. Selain itu pendugaan dengan VECM digunakan untuk melihat tingkat perubahan tertentu dengan analisis Impulse Respond Function dan Variance Decomposition.

\section{Uji Stasioneritas Data}

Tahap pertama yang dilakukan dalam mengolah data runtut waktu adalah dengan menguji stasioneritas atau unit root test. Data yang stasioner akan mempunyai kecenderungan untuk mendekati nilai rata-rata dan berfluktuasi di sekitar nilai rata-ratanya atau memiliki ragam yang konstan. Data yang tidak stasioner akan menghasilkan regresi yang lancung (spurious regression) yaitu regresi yang menggambarkan hubungan dua variabel atau lebih yang nampaknya signifikan secara statistik padahal kenyataannya tidak atau tidak sebesar regresi yang dihasilkan tersebut. Jika data stasioner maka metode yang dipilih adalah metode VAR dan jika data tidak stasioner maka menggunakan metode VECM.

Pengujian stasioneritas dilakukan dengan menggunakan uji akar menggunakan Augmented Dickey Fuller (ADF) Test. Misalkan model persamaan time series sebagai berikut:

$$
\mathrm{Y}_{\mathrm{t}}=\rho \mathrm{y}_{\mathrm{t}-1}+\varepsilon \mathrm{t}
$$

dengan mengurangkan kedua sisi persamaan tersebut dengan $\mathrm{y}_{\mathrm{t}-1}$ maka akan didapatkan persamaan,

$$
\Delta \mathrm{y}_{\mathrm{t}}=\delta \mathrm{y}_{\mathrm{t}-1}+\varepsilon_{\mathrm{t}}
$$

dimana $\Delta$ adalah perbedaan pertama (first difference) dan $\delta=(\rho-1)$ sehingga didapatkan hipotesis Ho : $\delta=0$ dan H1: $\delta<0$. Pada tes ini, jika nilai ADF statistik lebih kecil daripada Mac Kinnon Critical Value maka dapat disimpulkan bahwa series tersebut stasioner. Jika diketahui data tersebut tidak stasioner, maka dapat dilakukan differences non stasioner process.

\section{Pemilihan Lag Optimum}

Dalam VAR penentuan lag optimal sangat penting karena penentuan lag optimal berguna untuk menghilangkan masalah autokorelasi dalam sebuah sistem VAR. Penentuan lag optimal juga berguna untuk menunjukkan berapa lama reaksi suatu variabel terhadap variabel lainnya (Gustiani, et.al dalam Malahayati, 2011). Pemilihan Ordo atau lag dilakukan berdasarkan kriteria Akaike Information Criterion (AIC), Schwarz Information Criterion (SC), dan Hannan Quinnon (HQ). Lag yang dipilih adalah model dengan nilai AIC dan SC terkecil dan nilai HQ terbesar. Lag yang dipilih pada penelitian ini berdasarkan kriteria dengan SC terkecil.

$$
S C=\operatorname{AIC}(\mathrm{q})+(\mathrm{q} / \mathrm{T})(\log \mathrm{T}-1)
$$

dengan $\mathrm{q}$ adalah jumlah variabel, $\mathrm{T}$ adalah jumlah observasi dan AIC adalah Akaike Information Criteria dengan perhitungan,

$$
A I C=\log \left[\sum \varepsilon i^{2} / N\right]+2 k / N
$$

dengan $\sum \varepsilon i^{2}$ adalah jumlah residual kuadrat sedangkan $\mathrm{N}$ dan $\mathrm{k}$ adalah sampel jumlah variabel dari jumlah varibel yang beroperasi dalam persamaan tersebut.

\section{Uji Kointegrasi}


Setelah diperiksa kestasioneritasannya kita dapat mengujinya kembali dengan uji kointegrasi. Jika data stasioner pada first different maka perlu dilakukan pengujian untuk melihat terjadinya kointegrasi. Uji kointegrasi bertujuan untuk melihat keseimbangan jangka panjang dan memastikan adanya hubungan jangka panjang di antara variabel yang di observasi. Kointegrasi adalah suatu hubungan jangka panjang antara variabel - variabel yang meski secara individual tidak stasioner tetapi kombinasi linier antara variabel tersebut dapat menjadi stasioner. Adanya hubungan kointegrasi dalam sebuah sistem persamaan menandakan bahwa dalam sistem tersebut terdapat error correction model yang menggambarkan adanya dinamisasi dalam jangka pendek secara konsisten dengan hubungan jangka panjangnya.

\section{Uji Stabilitas}

Stabilitas dalam sistem VAR perlu diperhatikan dalam penentuan lag. Stabilitas VAR dapat dilihat dari nilai inverse roots karakteristik AR polinomialnya. Suatu sistem VAR dikatakan stabil apabila seluruh roots pada tabel AR roots-nya memiliki modulus lebih kecil dari satu dan semuanya terletak di dalam unit circle.

\section{Impulse Response Function (IRF) dan Forecast Error Variance Decomposition (FEVD)}

Impulse Respond Funtion adalah suatu metode yang digunakan untuk melihat respon suatu variabel akibat adanya guncangan atau shock pada suatu variabel endogen Metode ini juga menunjukan arah hubungan dan besarnya pengaruh suatu variabel endogen terhadap berbagai variabel endogen lainnya yang ada dalam suatu sistem dinamis VAR.

Forecast Error Variance Decomposition adalah metode yang digunakan untuk melihat bagaimana perubahan dalam suatu variabel yang ditunjukan oleh perubahan error variance dipengaruhi oleh variabel- variabel lainnya. Analisis ini digunakan untuk menghitung seberapa besar pengaruh acak guncangan dari variabel tertentu terhadap variable endogen. Dengan metode ini kita dapat melihat kekuatan dan kelebihan masing-masing variabel dalam mempengaruhi variabel yang lainnya dalam kurun waktu yang panjang.

\subsection{Model Penelitian}

Model yang digunakan dalam penelitian ini dibagi menjadi dua, yaitu pembiayaan UMKM melalui jalur bank konvensional dan bank syariah. Model I adalah model yang digunakan untuk melihat penyaluran kredit UMKM melalui perbankan konvensional, sedangkan Model II adalah model yang digunakan untuk melihat penyaluran pembiayaan UMKM melalui perbankan syariah. Model I dan II dijabarkan dalam tabel sebagai berikut:

\begin{tabular}{|c|l|}
\hline Model & \multicolumn{1}{|c|}{ Penjabaran } \\
\hline $\mathrm{I}$ & $\mathrm{CRD}_{\mathrm{t}}=f\left(\mathrm{IR}_{\mathrm{t}}, \mathrm{SBI}_{\mathrm{t}}, \mathrm{SBIS}_{\mathrm{t}}\right)$ \\
\hline $\mathrm{II}$ & $\mathrm{PYD}_{\mathrm{t}}=f\left(\mathrm{PLS}_{\mathrm{t}}, \mathrm{MARGIN}_{\mathrm{t}}, \mathrm{SBI}_{\mathrm{t}}, \mathrm{SBIS}_{\mathrm{t}}\right)$ \\
\hline
\end{tabular}




\section{HASIL DAN PEMBAHASAN}

\section{Hasil Uji Stasioneritas Data}

\begin{tabular}{|l|c|c|c|c|}
\hline \multirow{2}{*}{ Variabel } & \multicolumn{2}{c|}{ Level } & \multicolumn{2}{c|}{ First Diffrence } \\
\cline { 2 - 5 } & ADF-Statistic & t-statistic & ADF-Statistik & t-statistik \\
\hline KREDIT & -2.698830 & -3.493692 & $-6.808640^{* *}$ & -2.917650 \\
\hline IR & -2.019345 & -2.916566 & $-3.594928^{* *}$ & -2.916566 \\
\hline PYD & -0.008691 & -2.915522 & $-4.891885^{* *}$ & -2.916566 \\
\hline MARGIN & $-3.274322^{* *}$ & -2.915522 & -6.884884 & -2.918778 \\
\hline PLS & -2.013306 & -2.918778 & $-11.79131^{* *}$ & -4.930956 \\
\hline SBI & -2.502072 & -2.916566 & $-3.833385^{* *}$ & -2.916566 \\
\hline SBIS & -3.01749 & -2.915522 & $-6.070852^{* *}$ & -2.91765 \\
\hline
\end{tabular}

Sumber: Data diolah

Keterangan : ** : Signifikan pada nyata 5 persen

Dari hasil uji stasioneritas seluruh variabel stasioner pada first different kecuali variabel MARGIN yang stasioner pada tingkat level.

\section{Hasil Pengujian Lag Optimum}

\begin{tabular}{|c|c|c|}
\hline \multirow{2}{*}{ Lag } & \multicolumn{2}{|c|}{ AIC } \\
\cline { 2 - 3 } & Model I & Model II \\
\hline 0 & 34.59488 & 35.72875 \\
\hline 1 & 23.94378 & 29.29504 \\
\hline 2 & $23.57957^{*}$ & $29.18349 *$ \\
\hline
\end{tabular}

Sumber: Data diolah

Keterangan : * nilai AIC terkecil

Berdasarkan hasil pengujian lag optimum maka Model I dan Model II optimum pada lag kedua.

\section{Hasil Uji Stabilitas VAR}

Dari hasil uji stabilitas VAR, dapat disimpulkan bahwa sistem VAR bersifat stabil karena root yang diuji memiliki kisaran kurang dari satu, yatu berkisar antara 0.759231-0.398319 pada Model I dan berkisar antara 0.966520- 0.251941 pada Model II.

\section{Hasil Uji Kointegrasi Johansen}

\section{$\underline{\text { Model I }}$}

\begin{tabular}{|c|c|c|}
\hline Hipotesa & Trace Statistic & 5\% Critical Value \\
\hline None* $^{*}$ & 67.63257 & 47.85613 \\
\hline At most 1 & 27.02358 & 29.79707 \\
\hline At most 2 & 12.60481 & 15.49471 \\
\hline At most 3 & 0.884772 & 3.841466 \\
\hline
\end{tabular}


$\underline{\text { Model II }}$

\begin{tabular}{|c|c|c|}
\hline Hipotesa & Trace Statistic & 5\% Critical Value \\
\hline None* & 71.32552 & 69.81889 \\
\hline At most 1 & 38.78936 & 47.85613 \\
\hline At most 2 & 18.60038 & 29.79707 \\
\hline At most 3 & 5.809156 & 15.49471 \\
\hline At most 4 & 0.422953 & 3.841466 \\
\hline
\end{tabular}

Dari hasil uji kointegrasi pada Mdel I dan Model II didapatkan kesimpulan bahwa kedua model terkointegrasi dan menggunakan model VECM untuk estimasinya.

\section{Hasil estimasi VECM}

\begin{tabular}{|l|r|c|}
\hline \multicolumn{3}{|c|}{ MODEL I- Jangka Panjang } \\
\hline \multicolumn{1}{|c|}{ Variabel } & Koefisien & \multicolumn{1}{c|}{ Tanda } \\
\hline IR(-1) & 956664.44 & $(-)$ minus \\
\hline SBIS(-1) & $235707.2 * *$ & $(-)$ minus \\
\hline SBI(-1) & $454426.8 * *$ & $(-)$ minus \\
\hline Coef & 6946859 & \\
\hline
\end{tabular}

Keterangan: $* *=$ signifikan pada taraf nyata 5 persen

\begin{tabular}{|l|r|c|}
\hline \multicolumn{3}{|c|}{ Model II- Jangka Panjang } \\
\hline \multicolumn{1}{|c|}{ Variabel } & Koefisien & Tanda \\
\hline PLS(-1) & 190.5207 & - (minus) \\
\hline MARGIN(-1) & $116.4096^{* *}$ & + (positif) \\
\hline SBI(-1) & $1102.075^{* *}$ & + (positif) \\
\hline SBIS(-1) & $1092.085^{* *}$ & - (minus) \\
\hline C & 3468.55 & \\
\hline
\end{tabular}

Keterangan: $* *=$ signifikan pada taraf nyata 5 persen

Dari hasil estimasi jangka panjang, suku bunga SBI dan bonus SBIS memiliki pengaruh yang signifikan dan memiliki hubungan yang negatif terhadap kredit UMKM. Ketika terjadi kenaikan suku bunga SBI atau bonus SBIS maka perbankan akan lebih tertarik untuk mengalokasikan dananya di SBI karena menjanjikan return yang tinggi. Hal inilah yang menyebabkan jumlah dana kredit UMKM yang disalurkan akan menurun.

Di samping itu, terdapat satu variabel yang tidak signifikan mempengaruhi kredit UMKM yaitu suku bunga kredit. Hal ini terjadi karena struktur kredit UMKM di Indonesia masih didominasi oleh penawarannya yang lebih besar dari permintaannya. Jika permintaannya sangat kecil maka suku bunga tidaklah menjadi variabel utama dalam penyaluran kredit UMKM. Permintaan yang rendah tercermin dari jumlah UMKM yang menerima sumber dana dari perbankan. Pada tahn 2010 UMKM yang menerima dana perbankan baru mencapai 21,35 persen dan 49,18 persen menyatakan tidak berminat mendapatkan pembiayaan dari perbankan. Selain itu, penawaran kredit UMKM dari perbankan dipengaruhi oleh faktor lain seperti rentabilitas bank, tingkat profitabilitas bank dan keadaan makro ekonomi. 
Begitu juga dengan hasil uji estimasi VECM pada Model II, pada jangka pendek tidak ada variabel yang signifikan mempengaruhi pembiayaan UMKM. Hal ini terjadi karena suatu variabel membutuhkan waktu atau lag untuk bereaksi pada variabel lain sehingga umumnya reaksi suatu variabel terhadap variabel lainnya terjadi dalam jangka panjang.

Dari hasil estimasi jangka panjang, suku bunga SBI, bonus SBIS dan tingkat margin memiliki pengaruh yang signifikan terhadap pembiayaan UMKM melalui bank syariah. Margin memiliki pengaruh yang positif terhadap pembiayaan UMKM, apabila tingkat return atau margin keuntungan meningkat maka perbankan akan mendapat keuntungan yang lebih besar dari pembiayaan sehingga akan menaikan jumlah pembiayaan yang disalurkan.

Lain halnya dengan variabel bonus SBIS. Dari hasil estimasi terdapat hubungan negatif antara bonus SBIS dan pembiayaan UMKM. Hal ini terjadi karena apabila terjadi kenaikan bonus SBIS maka perbankan syariah akan lebih tertarik menyalurkan dana dengan pembelian SBIS karena memberikan return yang lebih tinggi dan menghadapi resiko yang lebih rendah dibandingkan dengan menyalurkan pembiayaan ke sektor UMKM.

Selain itu, variabel suku bunga SBI memiliki hubungan yang positif terhadap penyaluran pembiayaan UMKM dari perbankan syariah. Hal ini terjadi karena ketika terjadi kenaikan suku bunga SBI maka bank konvensional akan mengalihkan penyaluran dananya ke SBI sehingga kredit yang mereka tawarkan akan menurun. Kondisi ini dimanfaatkan oleh perbankan syariah dengan memberikan pembiayaan UMKM yang lebih besar karena bank konvensional sebagai saingannya sedang menurunkan penyaluran kreditnya.

Namun demikian, variabel PLS atau tingkat bagi hasil tidak signifikan mempengaruhi jumlah pembiayaan UMKM yang disalurkan. Hal ini terjadi karena pembiayaan dengan akad bagi hasil memiliki porsi yang lebih rendah dibandingkan dengan pembiayaan dengan akad jual beli. Porsi pembiayaan dengan akad bagi hasil (musyarakah dan mudharabah) hanya sebesar 35,29 persen dari pembiayaan total. Sedangkan porsi pembiayaan dengan akad jual beli (murabahah) mencapai 55,76 persen. 


\section{Simulasi Impulse Response Function}

a.

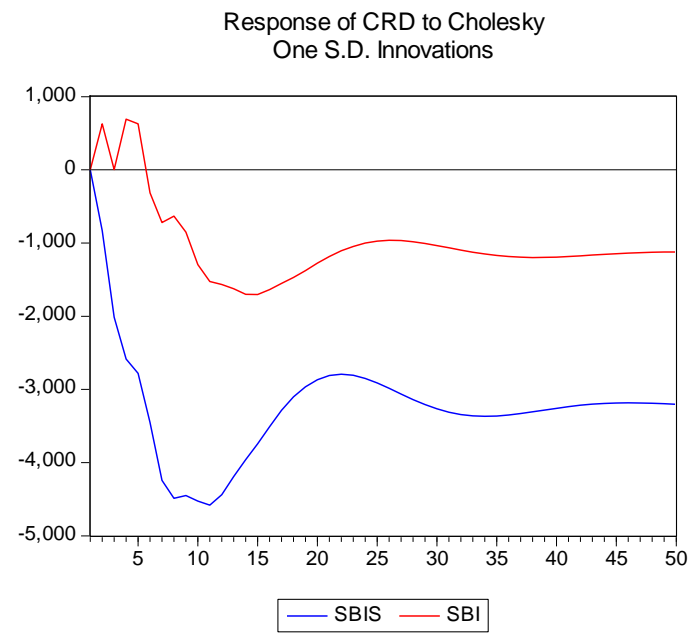

b.

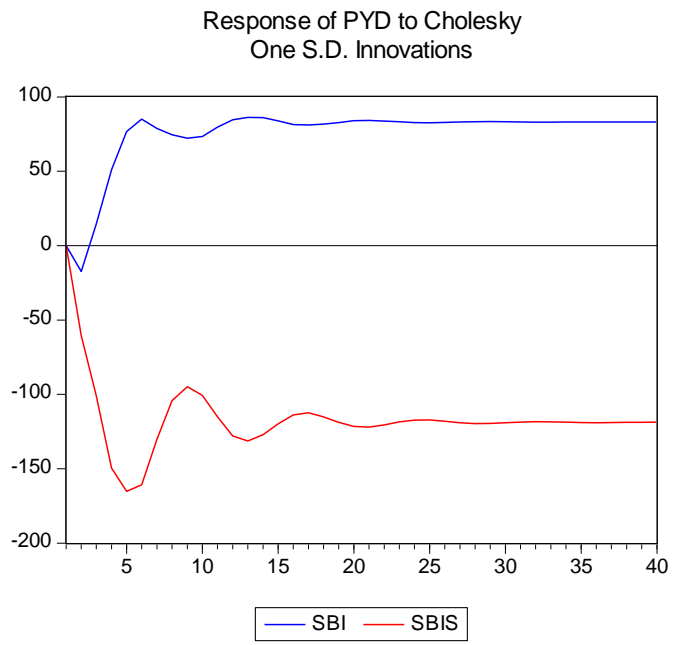

\section{Gambar 1 a) Respon Kredit UMKM Terhadap Guncangan SBIS dan SBI b) Respon Pembiayaan UMKM Terhadap Guncangan SBIS dan SBI}

Dari Gambar 4.1 dapat dibandingkan bahwa pembiayaan UMKM dari perbankan syariah lebih cepat stabil saat terjadi guncangan moneter. Kredit UMKM akan stabil pada periode ke 45 dan pembiayaan akan stabil pada periode ke 27. Hal ini mengindikasikan bahwa daya tahan pembiayaan dari bank syariah lebih baik dibandingkan dengan bank konvensional karena seluruh pembiayaan yang disalurkan oleh bank syariah menyentuh sektor riil. 

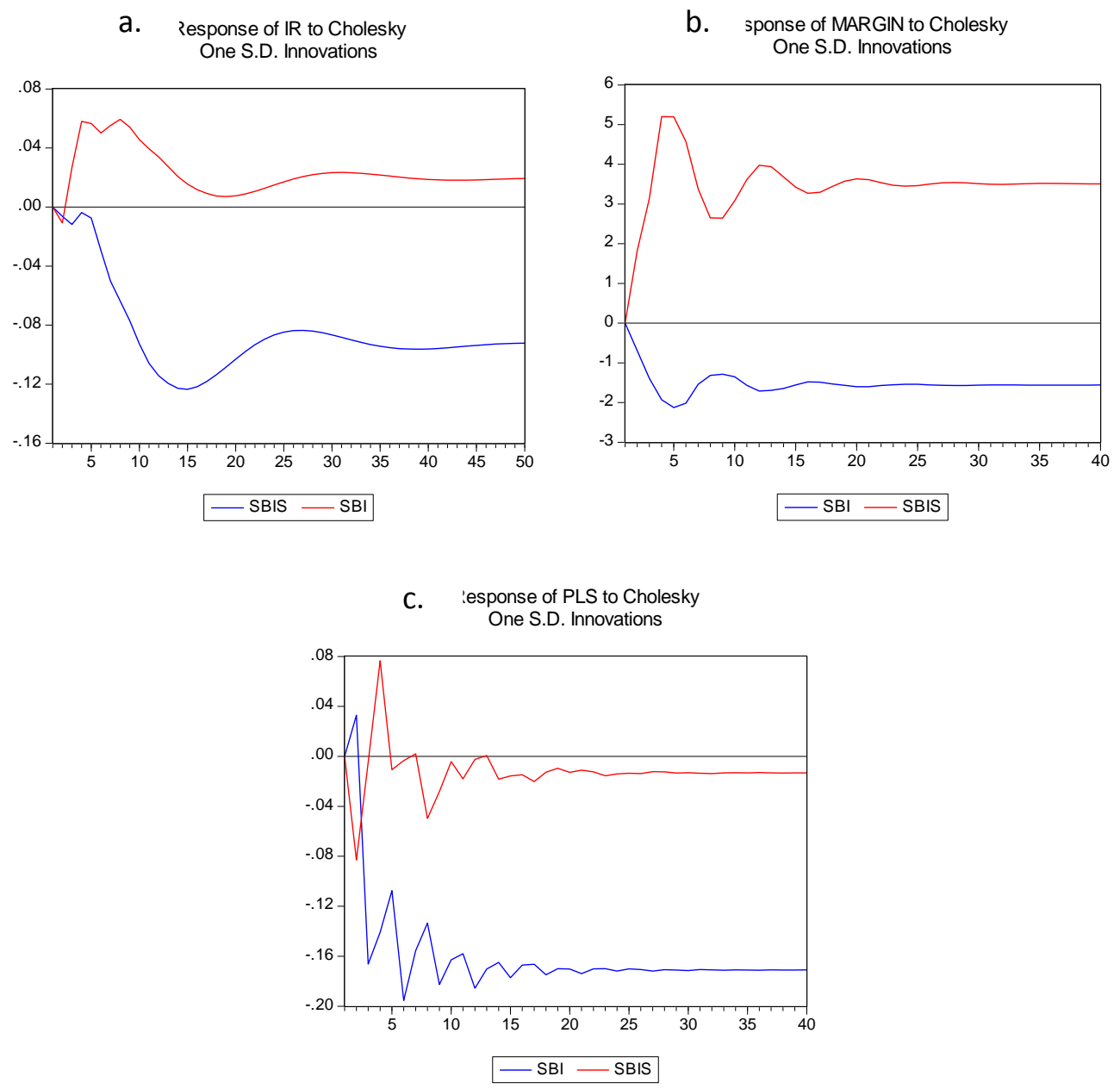

\section{Gambar 2 a) Respon Suku Bunga Kredit Terhadap Guncangan SBI dan SBIS b) Respon Margin Terhadap Guncangan SBI dan SBIS c) Respon PLS Terhadap Guncanga SBI dan SBIS}

Terlihat dari hasil simulasi pada Model I dan Model II guncangan moneter akan berpengaruh juga kepada return penyaluran dana perbankan, yaitu suku bunga kredit pada perbankan konvensional dan profit loss sharing (PLS) serta margin murabahah pada perbankan syariah. Saat terjadi guncangan moneter maka return dari perbankan syariah ( PLS dan Margin) lebih cepat stabil dibandingkan dengan suku bunga kredit. Hal ini terjadi karena jumlah pembiayaan UMKM dari perbankan syariah dari masih jauh lebih kecil dari perbankan konvensional sehingga apabila terjadi guncangan moneter maka perbankan syariah akan lebih cepat mengalami penyesuaian.

Dari hasil simulasi pada Model II, terdapat perbedaan respon ketika terjadi guncangan moneter pada variabel PLS dan Margin. Guncangan moneter di respon cukup fluktuatif oleh PLS dibandingkan dengan respon Margin yang relatif stabil. Hal ini terjadi karena penentuan besaran margin murabahah adalah tetap, sedangkan penentuan besaran PLS tergantung dari kondisi ekonomi. Maka dari itu ketika ada guncangan ekonomi yang dicerminkan oleh guncangan moneter maka pengaruhnya terhadap variabel PLS akan lebih besar dibandingkan dengan variabel Margin. 


\section{Simulasi Forecast Error Variance Decomposition}

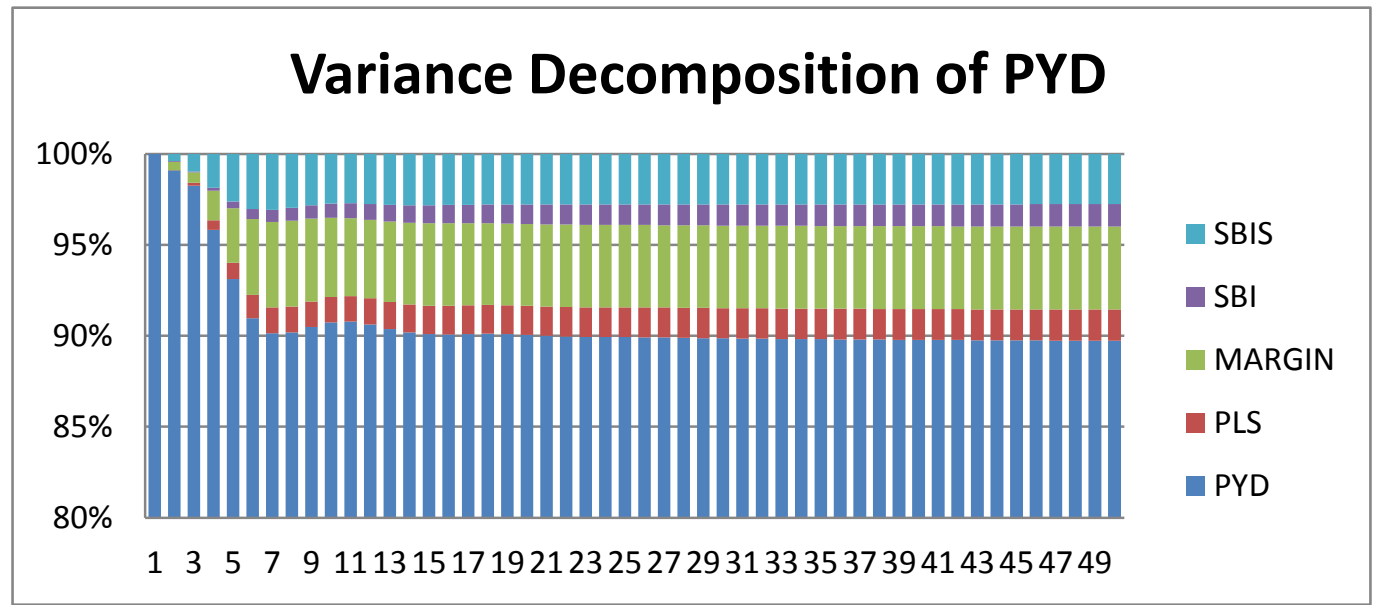

\section{Gambar 3 Hasil FEVD pada kredit UMKM Perbankan Konvensional (Model I)}

Dari hasil pengujian FEDV pada Model I, Pembiayaan UMKM dari perbankan syariah sebagian besar dipengaruhi oleh pembiayaan itu sendiri. Faktor lain yang mempengaruhi pembiayaan adalah margin murabahah dengan porsi sekitar 4,5 persen, bagi hasil pembiayaan dengan porsi sekitar 1,5 persen dan bonus SBIS dengan porsi 3 persen. Pengaruh SBI dalam mempengaruhi besarnya pembiayaan UMKM dapat dikatakan kecil karena porsinya hanya satu persen. Hal ini mengindikasikan bahwa dalam jangka panjang pengaruh SBI terhadap pembiayaan UMKM akan semakin kecil dan pengaruh SBIS terhadap pembiayaan akan semakin besar. Hal ini dikarenakan pembiayaan UMKM dari perbankan syariah mendapatkan pengaruh langsung dari SBIS sebagai salah satu instrumen moneter syariah pada saat transmisi moneter.

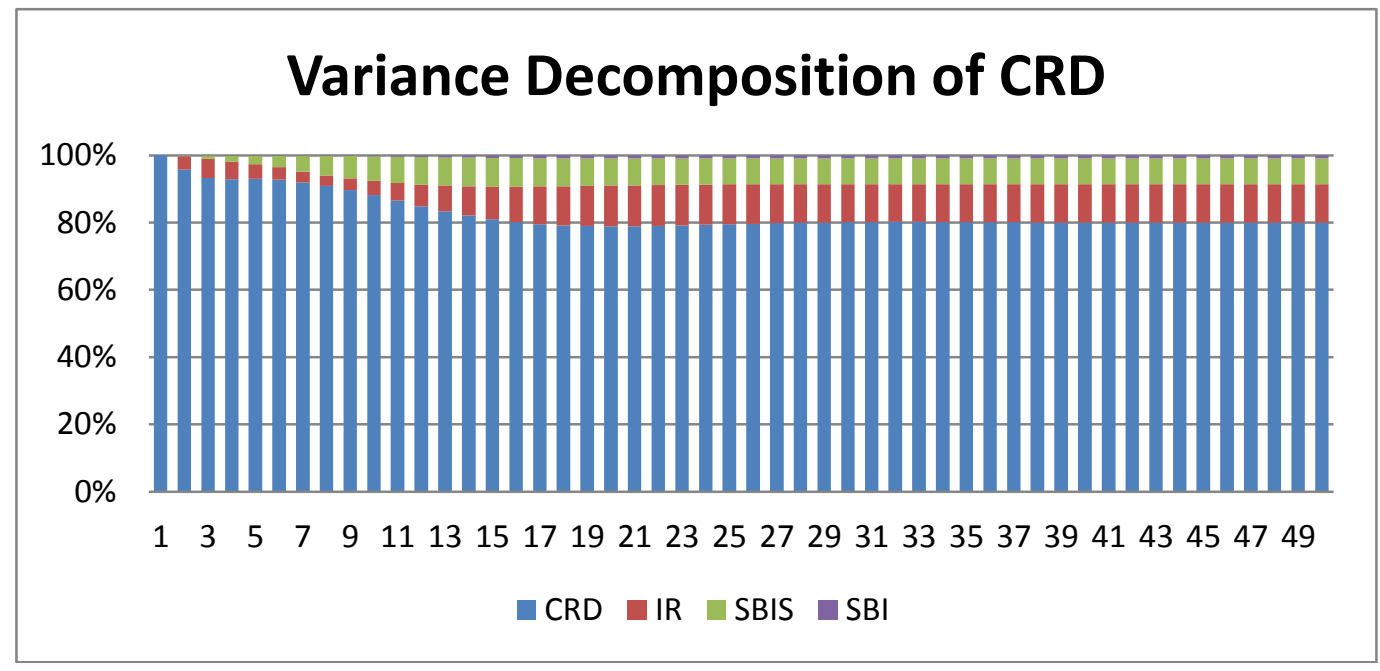

\section{Gambar 4 Hasil FEVD pada Kredit UMKM Perbankan Konvensional (Model II)}

Dari hasil pengujian FEDV pada Model II kredit UMKM dari perbankan konvensional dipengaruhi oleh kredit itu sendiri. Faktor lain yang mempengaruhi kredit UMKM adalah suku bunga kredit dengan porsi 12,5 persen, SBIS dengan porsi 13 persen dan SBI dengan porsi 0.35 persen. Dalam jangka panjang pengaruh SBIS semakin signifikan tetapi lain halnya dengan SBI. Hal ini mengindikasikan bahwa peran SBI semakin lama semakin tidak efektif dalam transmisi 
moneter melalui jalur kredit. Hasil ini diperkuat dengan penelitian yang dilakukan oleh Amaluddin (2005) yang menyatakan bahwa kebijakan moneter di Indonesia dengan menggunakan SBI semakin lama semakin kurang efektif. Selain itu, peran SBIS yang semakin besar menunjukan kinerja SBIS yang semakin baik.

\section{KESIMPULAN DAN SARAN}

Berdasarkan hasil penelitian yang telah dilakukan terdapat beberapa kesimpulan, yaitu:

a. Instrumen moneter konvensional yang diwakili oleh suku bunga SBI dan instrumen moneter syariah yang diwakili oleh SBIS secara signifikan berpengaruh terhadap pembiayaan UMKM baik melalui perbankan syariah maupun perbankan konvensional.

b. Dari jalur kredit perbankan konvensional, SBI memiliki hubungan yang negatif terhadap kredit UMKM. Begitu juga dengan SBIS yang memiliki hubungan yang negatif terhadap pembiayaan UMKM. Perbankan akan lebih tertarik mengalokasikan dananya di SBI atau SBIS ketika terjadi kenaikan return. Hal inilah yang menyebabkan jumlah penyaluran dana yang disalurkan ke sektor UMKM akan menurun.

c. Dari hasil IRF, guncangan moneter akan berpengaruh dengan cepat pada pembiayaan UMKM dari perbankan syariah dan kredit UMKM dari perbankan konvensional. Akan tetapi, saat pembiayaan UMKM dari perbankan syariah akan lebih cepat stabil dibandingkan dengan kredit UMKM dari perbankan konvensional. Begitu juga dengan respon return pembiayaan bank syariah (PLS dan Margin) yang lebih cepat stabil dibandingkan dengan suku bunga kredit perbankan konvensional.

d. Dari hasil FEVD, baik dari jalur perbankan syariah maupun perbankan konvensional instrumen yang paling berpengaruh adalah SBIS. SBI hanya memiliki pengaruh yang kecil, yaitu kurang dari satu persen pada perbankan syariah dan konvensional. Hal ini mengindikasikan bahwa peran SBI semakin lama semakin tidak efektif dalam transmisi moneter melalui jalur kredit.

Peran SBIS yang semakin signifikan pada penyaluran kredit UMKM baik pada perbankan syariah maupun konvensional mengindikasikan kinerja instrumen moneter syariah semakin baik. Untuk itu bank sentral sebagai otoritas moneter dapat memperkuat peran instrumen SBIS. Selain itu, transmisi kebijakan moneter lewat jalur kredit berjalan kurang optimal terlihat dari hasil FEDV yang menunjukan pengaruh instrumen moneter baik SBI atau SBIS yang tidak terlalu besar. Otoritas moneter harus ikut berpartisipasi mendorong penyaluran dana perbankan ke sektor UMKM mengingat peran UMKM yang sangat besar bagi perekonomian Indonesia.

\section{DAFTAR PUSTAKA}

Algaoud, Latifa M dan Meryn K Lewis. Perbankan Syariah, Prinsip, Praktek dan Prospek. 2001. Jakarta: PT Serambi Ilmu Semesta.

Amaluddin, Friady. 2005. Efektifitas Transmisi Kebijakan Moneter antara Bank Syariah dan Konvensional. [Tesis]. Depok: Fakultas Ekonomi, Universitas Indonesia.

Antonio, S. 1999. Bank Syariah dan Pengenalan Umum. Jakarta: Tazkia Institute dan Bank Indonesia, . 2000. Bank Syariah Dari Teori ke Praktek. Jakarta: Gema Insani.

Ascarya, 2012. Alur Transmisi dan Efektifitas Kebijakan Moneter Ganda di Indonesia. Buletin Ekonomi Moneter dan Perbankan Edisi Januari 2012. Jakarta. 2011. Disampaikan dalam perkuliahan Kebanksentralan dan Kebijakan Moneter. 7 Desember 2011, Bogor.

, Hasanah dan Achsani. 2008. Permintaan Uang dan Stabilitas Moneter dalam Sistem Moneter Ganda di Indonesia. Jurnal ISEI Perbankan Ekonomi Syariah,11. 
Ayuniyyah, Qurroh. 2010. Analisis Pengaruh Instrumen Moneter Syariah dan Konvensional Terhadap Pertumbuhan Sektor Riil di Indonesia.[Skripsi]. Bogor. Fakultas Ekonomi dan Manajemen, Institut Pertanian Bogor.

Bank Indonesia. 2010. Peraturan Perbankan. Jakarta: Bank Indonesia.

Direktorat Perbankan Syariah. Statistik Perbankan Syariah. Berbagai Edisi.Jakarta: Bank Indonesia.

Bank Indonesia.

Outlook Perbankan Syariah. Berbagai Edisi. Jakarta:

Fatwa DSN MUI Nomor IV, VII dan VIII. 2012. Berbagai Edisi. Jakarta, http://www.mui.or.id/index.php?option=com_docman\&task=doc_view\&gid=16 \&tmpl=component\&format=raw\&Itemid=73 [24 Maret, 2012 ]

Firdaus, Muhammad. 2011. Aplikasi Ekonometrika Untuk Data Panel dan Time Series. Bogor. IPB Press.

Gustiani, Ebrida Daisy, Ascarya, dan Effendy, Jaenal. 2010. Analisis Pengaruh Social Values Terhadap Jumlah Permintaan Uang Islam di Indonesia. Buletin Ekonomi Moneter dan Perbankan, April 2010.

Karim, Adiwarman. 2010. Bank Islam Analisis Fiqih dan Keuangan. Jakarta: PT Raja Garfindo Persada. 2008. Ekonomi Makro Islami. Jakarta: PT Raja Grafindo Persada.

Meydianawathi, L.H. 2007. Analisis Perilaku Penawaran Kredit Perbankan Kepada Sektor UMKM di Indonesia (2002-2006). Buletin Studi Ekonomi Volume 12 Nomor 2, 2007.

Mishkin, Frederic S. 2009. The Economics of Money, Banking, and Financial Markets. Addison-Wesley. World Student Series. New York.

Malahayati, Marissa. 2011. Analisis Fenomena Twin Deficit Pada Negara- Negara ASEAN. [Skripsi]. Bogor: Fakutas Ekonomi dan Manajemen, Institut Pertanian Bogor.

Mankiw, Gregory. 2007. Makroekonomi. Jakarta: Erlangga.

Muslim, Fauzal. 2008. Analisis Transmisi Kebijakan Moneter (Credit Channeling) Terhadap Posisi Kredit Investasi Di Indonesia Periode 2001:1-2007:6. [Skripsi]. Bandung: Fakultas Ekonomi, Universitas Padjajaran.

Nugraheni, Sri Retno Wahyu. 2011. Analisis Daya Tahan Perbankan Syariah terhadap Fluktuasi Ekonomi di Indonesia. Bogor: Fakultas Ekonomi dan Manajemen Departemen Ilmu Ekonomi, Institut Pertanian Bogor.

Nursechafia. 2010. Pengaruh Guncangan Variabel Makroekonomi Terhadap Dana Pihak Ketiga dan Kredit Perbankan Pada Sistem Perbankan Ganda di Indonesia.[Skripsi]. Bogor: Fakultas Ekonomi dan Manajemen, Institut Pertanian Bogor.

Oliver, Hulsewig. 2003. Bank Behaviour, Interest Rate Targeting and Monetary Policy Transmission.Wurzburg Economic Paper http://hdl.handle.net/10419/48467 [27 Maret, 2012].

Rusydiana S.R. 2009. Mekanisme Transmisi Syariah pada Sistem Moneter Ganda di Indonesia. Buletin Ekonomi Moneter dan Perbankan: volume 11 Nomor 4 Edisi April.

Subandi, Slamet. 2010. Potensi Pengembangan Permodalan UMKM dari Pinjaman Perbankan. Jakarta: Kementrian Negara Koperasi dan UMKM.

Sugiyono, F.X. 2003. Instrumen Pengendalian Moneter: Operasi Pasar Terbuka. Seri Kebanksentralan No.10. Pusat Pendidikan dan Studi Kebanksentralan (PPSK) Bank Indonesia, Jakarta. 
Tambunan, Tulus.2009. UMKM di Indonesia. Jakarta: Ghalia Indonesia.

Wirjo,Wiloejo Wijono. 2005. Pemberdayaan Lembaga Keuangan Mikro Sebagai Salah Satu Pilar Sistem Keuangan Nasional: Upaya Konkrit Memutus Mata Rantai Kemiskinan.Kajian Ekonomi dan Keuangan. Jakarta.

Wulandari, Tatu Nia. 2008. Fenomena Disintermediasi Perbankan Pasca Krisis dan Pengaruhnya Terhadap Sektor Riil dan Pertumbuhan Ekonomi [Skripsi]. Bogor: Fakultas Ekonomi dan Manajemen, Institut Pertanian Bogor.

Zanikhan, Muhammad Sadeli. 2009. Studi Akad Syariah dalam Penerbitan Sertifikat Bank Indonesia Syariah.[Skripsi]. Palembang: IAIN Raden Fatah Palembang. 